\title{
COMPARING DIFFERENT METHODS FOR ESTIMATING ECONOMIC VALUES IN SELECTION INDEX FOR PRE-WEANING BODY WEIGHTS OF FRIESIAN HEIFERS IN EGYPT
}

\author{
E. Faid-Allah and Elham Ghoneim
}

Department of Animal Production, Faculty of Agriculture, Minoufiya University, Egypt

\section{SUMMARY}

This study was carried out to compare different estimates of economic values by different methods as regression (Beta), regression (b), Lamont, Sharma, profit-2004, profit-2012, FAO-2011 and Unity case and their effect on expected genetic gains and possibility of genetic improvement of pre-weaning body weights of Friesian heifers. Data were collected allover 16 years from 1995 to 2010 and include records of 1748 progeny from 61 sires and 846 dams at the Experimental and Researches Unit of Animal Production (Tokh Tanbisha) in the middle Delta, that belongs to Faculty of Agriculture, Minoufiya University, Egypt. Selection indices included eight general indices constructed of body weights at birth $\left(W_{0}\right), 30\left(W_{30}\right), 60\left(W_{60}\right)$ and $90(W W)$ days of age. Estimates of genetic and phenotypic parameters for studied body weights were computed and used to construct selection indices for improving studied traits in Friesian heifers.

The comparisons of the various selection indices indicated that using Sharma index $\left(I_{4}\right)$ achieved to the highest efficiency $\left(R_{I H}=0.5180\right)$, but this value was not far from the efficiency of $I_{3}$ - Lamont $\left(R_{I H}=0.5117\right), I_{1}$-regression (Beta) $\left(R_{I H}=0.5051\right), I_{5^{-}}$Profit-2004 $\left(R_{I H}=0.5047\right), I_{6^{-}}$Profit-2012 $\left(R_{I H}=0.5002\right)$, and $I_{2}$ - regression $(b)\left(R_{I H}=0\right.$. 0.4998).The expected genetic gains per generation for different methods were ranged between 0.6763 and $0.752 \mathrm{~kg}$ for $W_{0}, 1.33$ and $1.224 \mathrm{~kg}$ for $W_{30}, 0.863$ and $1.1 \mathrm{~kg}$ for $W_{60}$ and 0.886 and 1.043 for $W W$ at $(i=1)$.

It could be suggested that methods of FAO-2011 for being applicable and easy way to estimate economic values by breeders and their desired goals for selection, and multiple regression models, regression (Beta) for its stability and reliability and it takes correlation among selection criterion into consideration.

Keywords: Body weight, Genetic parameter, Selection index, Multi-Source, Restriction, Desired gain, Friesian heifers

\section{INTRODUCTION}

For many decades the researchers used many different methods to estimate the relative emphasis for economic traits that includes in selection indices. Defining objectives in economic terms is scarce and difficult enough in the Middle East especially in small holders because of the greater environmental and managerial complexity.

Birth weight is an important performance factor in beef and dairy cattle and has been studied by many researchers (Swali and Wathes, 2006; Shahzad et al., 2010 and Segura-Correa et al., 2012). Birth weight is used as a first measure of growth performance in animals and it is the easiest and most reliable measure of growth during the pre-natal period and postpartum period. Birth weight of calves is often considered in genetic improvement programs for many reasons: 1) it is easily measured and 2) it is correlated with a number of other performance traits (Sahin et al., 2012). Selection indexes allow the animal breeder to apply the appropriate economic weight or relative emphasis on traits to be improved. Animal breeding is always based on a multi-trait basis. The main traits as a selective criterion for pre-weaning growth traits of calves are their live body weights like birth weight and weaning weight (Oudah and El-Awady, 2006).

Selection index was developed by Hazel and Lush (1942) and Hazel (1943) as a method of selection for more than one trait at the same time. This method helps breeders to rank and evaluate the individuals on their total breeding values by condensing and summarizing the breeding values of the different economic traits in one total score for each one. Multiple trait selection requires the definition of a breeding goal including individual traits weighted according to their relative contribution to efficiency of production as expressed by economic values (Hazel, 1943).

This study was carried out to estimates the genetic parameters of pre-weaning body weights of Friesian heifers in Egypt, and to compare different estimates of economic values by different methods as regression (b), regression (beta), Lamont, Sharma, profit2004, profit-2012, FAO-2011 and Unity case 
and their effect on expected genetic gains and possibility of genetic improvement of preweaning body weights of Friesian heifers

\section{MATERIALS AND METHODS}

Data used for this study were obtained from the Experimental and Researches Unit of Animal Production at Tokh Tanbisha, in the middle Delta, which belongs to Faculty of Agriculture, Minoufiya University, Egypt; through 16 years from 1995 to 2010. Data included body weights at birth, 30, 60 and 90 days of age in Friesian heifers (records of 1748 progeny of 61 sires and 846 dams). Calves were mainly produced through AI (imported frozen semen of Friesian sires). The management and rearing of these calves were described by Ghoneim et al. (2006)

Genetic parameters were estimated by derivative free REML with a simplex algorithm using the Multiple Trait DerivativeFree Restricted Maximum Likelihood (MTDFREML) programs of Boldman et al. (1995). The animal model in matrix notation was: $\quad(\mathbf{Y}=\mathbf{X b}+\mathbf{Z a}+\mathbf{e})$

Where: $\mathbf{Y}=$ the vector of observations (body weights at birth $\left(\mathrm{W}_{0}\right), 30\left(\mathrm{~W}_{30}\right), 60\left(\mathrm{~W}_{60}\right)$ and $90(\mathrm{WW})$ days of age); $\mathbf{b}=$ the vector of fixed effects (i.e. parity, year, season of birth);

$\mathbf{a}=$ the vector of random additive genetic direct effects; $\mathbf{X}$ and $\mathbf{Z}=$ known incidence matrices relating observations to the respective; $\mathbf{e}=$ vector of residual effects $(0$, $\left.I \sigma_{\mathrm{e}}{ }^{2}\right)$.

Selection Index Program (Wagenaar et al., 1995) and Matlab program (Matlab, 2002) were used to construct the selection indices. The four studied traits were used to construct eight selection indices. Selection index obtained by solving the following equation:

$$
I=b_{1} P_{1}+b_{2} P_{2}+\cdots b_{n} P_{n}=\sum_{i=1}^{n} b i P i
$$

Where: $\mathbf{I}=$ selection index, $\mathbf{b i}=$ index weights for each trait in the index;

$\mathbf{P}_{\mathrm{i}}=$ phenotypic measurement for each trait in the index.

The general index was obtained by solving the following equations given in matrix expression according to Cunningham (1969):

$$
\mathbf{P b}=\mathbf{G v} \text { to give } \mathbf{b}=\mathbf{P}^{-\mathbf{1}} \mathbf{G v}
$$

Where: $\mathbf{P}=$ Phenotypic (co)variances matrix;

$\mathbf{G}=$ Genetic (co)variances matrix;

$\mathbf{v}=$ Economic weights column vector;

$\mathbf{b}=$ Weighting factors column vector.

Furthermore, the other different properties of the selection index were calculated as following:

Standard deviation of the index $(\sigma \mathrm{i})=\sqrt{ } \mathrm{b}^{\prime} \mathrm{Pb}$, Standard deviation of the aggregate genotype $(\sigma \mathrm{t})=\sqrt{ }_{\mathrm{v}^{\prime} \mathrm{Gv}}$
Correlation between the index and the aggregate genotype $\left(\mathrm{R}_{\mathrm{IH}}\right)=\sigma \mathrm{i} / \sigma \mathrm{t}$

The expected genetic change $(\Delta \mathrm{G})$ for each trait, after one generation of selection on the index was obtained by solving either of the following equations (Van der Werf and Goddard, 2003):

$$
\Delta \mathbf{G i}=\left(\boldsymbol{i} \mathbf{b}^{\prime} \mathbf{G i}\right) / \sigma \mathbf{i} .
$$

Where: $\boldsymbol{i}=$ Selection intensity;

$\boldsymbol{\sigma} \mathbf{i}=$ Standard deviation of the index;

$\mathbf{G i}=$ the $i^{\text {th }}$ column of the $\mathrm{G}$ matrix.

The economic values (v) were calculated by eight methods:

(1) regression (Beta) method (multipleregression): were calculated depends on Beta (standardized coefficients) in case of WW was dependent variable as a main target in this study and $\mathrm{W}_{0}, \mathrm{~W}_{30}$ and $\mathrm{W}_{60}$ were independent variables.

(2) regression (b) method (multipleregression): were calculated depends on unstandardized coefficients in case of WW was dependent variable as a main target in this study and W0, W30 and W60 were independent variables.

(3) Lamont method (Lamont, 1991) were calculated as $\boldsymbol{a}_{\mathrm{i}}=\mathrm{v}_{\mathrm{i}}($ Economic value $)=T / h^{2} i$ where: $\quad \mathbf{T}=h^{2}{ }_{w 0}+h^{2}{ }_{w 30}+h^{2}{ }_{w 60}+h^{2}{ }_{w 90}$.

(4) Sharma, were calculated as $1 / \sigma p$, where: $\sigma p$ is phenotypic standard deviation of each trait (Sharma, 1982 and Sharma and Basu, 1986).

(5 \& 6) Profit method, as reported by Oudah and El-Awady (2006) based on prices of 2004 and 2012.

(7) FAO-Breeder method, reported by FAO (2011), was calculated depends on one hundred points are divided between these four traits by experts (eleven experts), preferably in a panel, who are aware of the cost and return structure in the growth operation. Assume that the consensus was 100 points for growth performance. The ratio becomes in average 35:14:14:37 for $\mathrm{W}_{0}, \mathrm{~W}_{30}, \mathrm{~W}_{60}$ and $\mathrm{W}_{90}$, respectively. To standardize the units of measurement, these values must be inversely weighed by the additive genetic standard deviation $\sigma_{\mathrm{a}}$ (the square root of the numerator of the heritability) of each trait. If $\sigma_{a}$ for the traits are 1.818, 2.366, 2.439 and $2.322 \mathrm{~kg}$, respectively, then the final breeding goal trait values would be $35 / 1.818=19.255,14 / 2.366=$ $5.917,14 / 2.439=5.739$, and $37 / 2.322=$ 15.937 as absolute values; or 1.21: 0.37: 0.36: 1 as a relative emphasis for $\mathrm{W}_{0}, \mathrm{~W}_{30}, \mathrm{~W}_{60}$ and $\mathrm{W}_{90}$, respectively.

(8) Unity case was assumed that all traits equal one.

Spearman's rank correlation coefficients were calculated to compare matching among the estimates of economic values under study as mentioned at Table (2) and matching the 
ranking of animals via the eight selection indices under study as mentioned at Table (5)

\section{RESULTS AND DISCUSSION}

\section{Descriptive statistics:}

Table (1) shows the descriptive statistics of W0, W30, W60 and WW as arithmetic means. The W0 average of Friesian heifers obtained in the study agrees with Gaffer et al. (2005) $(32.81 \mathrm{~kg}$ ), but lower than $39.2 \mathrm{~kg}$ (Baumgard et al., 2002). The WW average of heifers at the present study is lower than that reported by Gaffer et al. (2005) who reported $94.97 \mathrm{~kg}$ at 105 days of age and greater than $73.89 \mathrm{~kg}$ that reported by Abdel-Glil and Elbanna (2001). The coefficient of phenotypic variability decreased with advancing of age from birth to weaning.

\section{Estimates of economic values:}

Table (2) shows the eight different estimates of relative economic values for preweaning body weights and its rank correlation that revealed high correlation among regression (Beta), Lamont and Profit-2004. On the other hand, there are no rank correlations among the other estimates.

\section{Genetic and phenotypic parameters:}

Estimates of heritability $\left(\mathrm{h}^{2}\right)$ as well as genetic correlations $\left(\mathrm{r}_{\mathrm{G}}\right)$ and phenotypic correlations $\left(\mathrm{r}_{\mathrm{P}}\right)$ for and among different body weights are presented in Table (3). Heritability estimates for body weights at birth, 30, 60 and 90 days of age were $0.23,0.30,0.28$ and 0.21 , respectively. These estimates are moderate and in agreement with those estimates obtained by Oudah and El-Awady (2006) (0.24 and 0.28) for birth weight and weaning weight in Friesian calves, respectively, Oudah and Mehrez (2000) (0.24 and 0.27), El-Awady (2004) (0.28 and 0.24) for W0 and WW in Friesian calves, resp., and Cucco et al. (2009) (0.23) for birth weight in Braunvieh cattle. On the other hand, high values of heritability for birth weight $(0.57,0.59,0.62$ and 0.65$)$ via different arithmetic methods were obtained by Aksakal et al. (2012). According to the present moderate $\mathrm{h}^{2}$ estimates, it could be concluded that the genetic improvement of WW can be achieved through selection. Oudah and ElAwady (2006) came to the same conclusion on Friesian calves.

Significant estimates of phenotypic correlations $\left(r_{P}\right)$ and genetic correlations $\left(r_{G}\right)$ among traits were positive (Table 3). ElAwady (2003) reported that there were positive genetic and phenotypic correlations between birth weight and weaning weight. El-Awady (2003) using another set of data of Friesian calves, found that genetic and phenotypic correlation between birth and weaning weights were 0.49 and 0.56 , respectively. Weaning weight was significantly and positively correlated with all traits under study imply that the W0 could be increased as a result of selection for the heavier WW $(0.65$, Shemeis et al., 2006, and 0.50, Koots et al., 1994).

\section{Selection index:}

General selection indices are shown in Table (4). The general index is considered as the main index as it includes all traits under selection program without any reduction or restrictions.

Eight selection indices were constructed based on eight different methods of estimating economic values; regression (Beta), regression (b), Lamont, Sharma, Profit-2004, Profit-2012, FAO-2011 and Unity case (Table 4). The original selection index (I) included $\mathrm{W}_{0}, \mathrm{~W}_{30}$, $\mathrm{W}_{60}$ and $\mathrm{WW}$. The comparisons of the various selection indices indicate that using different methods of economic values ranged from 0.49 to 0.51 for their efficiencies of selection in absolutes $\left(\mathrm{R}_{\mathrm{Ih}}\right)$. Sharma index $\left(\mathrm{I}_{4}\right.$-Sharma $)$ achieved to $\left(\mathrm{R}_{\mathrm{IH}}=0.5180\right)$ as a highest value, but this value was not far from that of, $\mathrm{I}_{1}$ regression (Beta) $\left(\mathrm{R}_{\mathrm{IH}}=0.5051\right), \mathrm{I}_{2}$-regression (b) $\left(\mathrm{R}_{\mathrm{IH}}=0\right.$. 0.4998), $\mathrm{I}_{3}$-Lamont $\left(\mathrm{R}_{\mathrm{IH}}=0.5117\right)$, $\mathrm{I}_{5}$-Profit-2004 $\quad\left(\mathrm{R}_{\mathrm{IH}}=0.5047\right), \quad \mathrm{I}_{6}$-Profit-2012 $\left(\mathrm{R}_{\mathrm{IH}}=0.5002\right), \mathrm{I}_{7}-\mathrm{FAO}-2011 \quad\left(\mathrm{R}_{\mathrm{IH}}=0.4979\right)$ and $\mathrm{I}_{8}$-Unity case $\left(\mathrm{R}_{\mathrm{IH}}=0.5179\right)$. The efficiency of an index is not very sensitive to changes in the economic weights (Vandepitte and Hazel, 1977).

It was clear that the economic vectors were affected by the method used. For first two methods (Regression), Its economic values depends on how independent variables imply in the dependent variable, In method three (Lamont) depending on heritability value of the trait, gives high economic weight for the trait having low heritability, Method four (Sharma) low op showed the highest economic vector. Methods number five and six that had high profit trait showed the highest economic vector, but it depends on prices and its change from time to time and the customer demands. Method of FAO-2011 that depends on desired goals of breeders there are no high differences in expected genetic gains that obtained by regression (Beta), Lamont and Profit-2004. That results due to high rank correlation among them as shown in Table (2). On the other hand, there are fluctuations of weaning weight and weight at 60 days of age.

Therefore, the authors suggest methods of FAO-2011 for being applicable and easy way to estimate economic values by breeders and their desired goals for selection, and multiple regression models especially regression (Beta) for its stability and reliability. It takes the 
correlations among selection criterion into consideration.

\section{The expected genetic gain:}

The expected genetic gain per generation for each trait is presented in table (4). The expected genetic gains per generation for regression (Beta) index were 0.678, 1.184, 1.009 , and $0.9891 \mathrm{~kg}$ at $(i=1)$ for $\mathrm{W}_{0}, \mathrm{~W}_{30}$, $\mathrm{W}_{60}$ and WW, respectively. The expected genetic gain per generation $(i=1)$ in regression (b) index, were $0.7056,1.133,0.8626$, and $1.043 \mathrm{~kg}$ at $(i=1)$ for $\mathrm{W}_{0}, \mathrm{~W}_{30}, \mathrm{~W}_{60}$ and $\mathrm{WW}$, respectively. The expected genetic gain per generation $(i=1)$ in Lamont index, were $0.6913,1.207,1.057$, and $0.9367 \mathrm{~kg}$ at $(i=1)$ for $\mathrm{W}_{0}, \mathrm{~W}_{30}, \mathrm{~W}_{60}$ and $\mathrm{WW}$, respectively. The expected genetic gain per generation $(i=1)$ in Sharma index, were 0.6911, 1.222, 1.099, and $0.8861 \mathrm{~kg}$ at $(i=1)$ for $\mathrm{W}_{0}, \mathrm{~W}_{30}, \mathrm{~W}_{60}$ and $\mathrm{WW}$, respectively. The expected genetic gain per generation $(i=1)$ in Profit-2004 index, were $0.7022,1.18,1.002$, and $0.9775 \mathrm{~kg}$ at $(i=1)$ for $\mathrm{W}_{0}, \mathrm{~W}_{30}, \mathrm{~W}_{60}$ and $\mathrm{WW}$, respectively. The expected genetic gain per generation $(i=1)$ in Profit-2012 index, were $0.7278,1.158,1.015$, and $0.9538 \mathrm{~kg}$ at $(i=1)$ for $\mathrm{W}_{0}, \mathrm{~W}_{30}, \mathrm{~W}_{60}$ and $\mathrm{WW}$, respectively. The expected genetic gain per generation $(i=1)$ in FAO-2011 index, were $0.7518,1.133,0.9134$, and $0.9869 \mathrm{~kg}$ at $(i=1)$ for $\mathrm{W}_{0}, \mathrm{~W}_{30}, \mathrm{~W}_{60}$ and $\mathrm{WW}$, respectively. $\mathrm{I}_{7^{-}}$ FAO had the highest $\Delta \mathrm{G}$ for $\mathrm{W}_{0}(0.752 \mathrm{~kg})$, and $\mathrm{I}_{2}-\mathrm{Reg}$ had the highest $\Delta \mathrm{G}$ for WW (1.043 $\mathrm{kg})$.

The difference of expected genetic gain per generation for $\left(\mathrm{V}_{1-7}-\right.$ Unity case $)$ as a percent for each trait is presented in Table (4). The expected genetic gains per generation for birth weight $\left(\mathrm{W}_{0}\right)$ were increased by $0.3,4.4,2.2$, $2.2,3.8,7.6$ and $11.2 \%$ than $\Delta \mathbf{G}$ of Unity case for $\mathrm{V}_{1}, \mathrm{~V}_{2}, \mathrm{~V}_{3}, \mathrm{~V}_{4}, \mathrm{~V}_{5}, \mathrm{~V}_{6}$ and $\mathrm{V}_{7}$, respectively; The expected genetic gains per generation for body weight at 30 day $\left(\mathrm{W}_{30}\right)$ were decreased by $-3.3,-7.4,-1.4,-0.2,-3.6,-5.4$ and $-7.4 \%$ than $\Delta \mathbf{G}$ of Unity case for $\mathrm{V}_{1}, \mathrm{~V}_{2}, \mathrm{~V}_{3}, \mathrm{~V}_{4}, \mathrm{~V}_{5}$, $\mathrm{V}_{6}$ and $\mathrm{V}_{7}$, respectively; The expected genetic gains per generation for body weight at 60 day $\left(\mathrm{W}_{60}\right)$ were decreased by $-8.3,-21.5,-3.9,-0.1$, $-8.9,-7.7$ and $-17.0 \%$ than $\Delta \mathbf{G}$ of Unity case for $\mathrm{V}_{1}, \mathrm{~V}_{2}, \mathrm{~V}_{3}, \mathrm{~V}_{4}, \mathrm{~V}_{5}, \mathrm{~V}_{6}$ and $\mathrm{V}_{7}$, respectively; and the expected genetic gains per generation for weaning weight (WW) were increased by 9.9, 15.9, 4.1, 8.7, 6.0 and $9.7 \%$ than $\Delta \mathbf{G}$ of Unity case for $\mathrm{V}_{1}, \mathrm{~V}_{2}, \mathrm{~V}_{3}, \mathrm{~V}_{5}, \mathrm{~V}_{6}$ and $\mathrm{V}_{7}$, respectively; and decreased by $-1.5 \%$ than $\Delta \mathbf{G}$ of Unity case for $\mathrm{V}_{4}$.

\section{Rank comparison among selection indices} used different estimates of economic values:

The spearman rank correlation coefficients estimated among the animals under study on the bases of the general index by those methods were high (Table 5). It indicates that the order of ranking by the eight methods were in the same direction. Thus, the breeder can use any of eight methods with some restrictions on Sharma method that it may be disturbed by abnormal values which included when calculate standard deviation.

\section{CONCLUSION}

The authors suggest methods of FAO-2011 for being applicable and easy way to estimate economic values by breeders and their desired goals for selection, and multiple regression models especially regression (Beta) for its stability and reliability. Regression (Beta) takes the correlations among selection criterion into consideration.

\section{REFRENCES}

Abdel-Glil, M.F. and M.K. Elbanna, 2001. Genetic and non-genetic analysis for body weight traits of calves in a herd of Friesian cattle in Egypt. Minufiya J. Agric. Res. 26 (1): 99.

Aksakal, V., B. Bayram, M. Yanar and O. Akbulut, 2012. Estimation of variance components and heritability of birth weight through different methods in Swedish Red and White cattle. J. Animal and Plant Sciences, 22(1): 39.

Baumgard, L.H., W.J. Weber, G.W. Kazmer, S.A. Zinn, L.B. Hansen, H.C. Jones and B.A. Crooker, 2002. Effects of selection for milk yield on growth hormone response to growth hormone releasing factor in growing Friesian calves. J. Dairy Sci., $85: 2529$.

Boldman, K.G., L.A. Kriese, L.D. Van Vleck and S.D. Kachman, 1995. A manual for use of MTDFREML. A set of programs to obtain estimates of variances and covariances. ARS, USDA, Washington, D.C.

Cunningham, E., 1969. Animal Breeding Theory. Landbrukshofhandelen, Univ. Laget, Vollebek, Oslo.

Cucco, D.C., J.B.S. Ferraz, L.F.B. Pinto, J.P. Eler, J.C.C. Balieiro and E.C. Mattos, 2009. Genetic parameters for pre-weaning traits in Braunvieh cattle. Genetics and Molecular Res., 8 (1): 291.

El-Awady, H.G., 2003. Maternal components as related to direct components for some growth traits of Friesian calves in Egypt. J. Agric. Sci., Mansoura Univ., Egypt, 28: 3393.

El-Awady, H.G., 2004. The influence of maternal effects on the efficiency of selection index for growth traits of Friesian 
calves from birth to weaning. J. Agric. Res. Tanta Univ., 30: 559.

FAO, 2011. Breeding strategies for sustainable management of animal genetic resources. Arabic version by Galal, S., page73:1-132.

Franklin, I.R., 1986. Breeding ruminants for the tropics. Proc. $3^{\text {rd }}$ World Congr. Genet. Appl. Livest. Prod. II, 451.

Gaffer, H.M.A., A.A. Shitta and E.A. Omer, 2005. Probiotic supplementation for suckling Friesian calves 1- Productive performance. Egyptian J. Nutrition and Feeds 8: 163.

Ghoneim, E.M., M.A. El-Saied, I.M. Saddick and E. Faid-Allah, 2006. Estimates of some genetic parameters for growth performance of Friesian calves in Egypt. Minufiya J. Agric. Res. 31 (6):1375.

Güler, O., M. Yanar and O. Akbulut, 2010. Variance component estimation for heritability of gamma lactation curve traits of Holstein Friesian cattle. Indian Vet. J., $87: 35$.

Hazel, L.N., 1943. The genetic basis for constructing selection indices. Genetics, 28: 476.

Hazel, L.N. and J. Lush, 1942. The efficiency of three methods of selection. J. Heredity 33: 393.

Koots, K.R., J.P. Gibson and J.W. Wilton, 1994. Analyses of published genetic parameter estimates for beef production traits. 2- Phenotypic and genetic correlations. Anim. Breed, Abst, 62: 825.

Lamont, S.J., 1991. Selection for immune response in chickens. Presented at the $40^{\text {th }}$ Annual National Breeder Round Table, May 2-3. St. Louis, Missouri.

Matlab, 2002. The Language of Technical Computing. Release 13 by The MathWorks, Inc.

Oudah, E.Z.M. and H.G. El-Awady, 2006. Selection indexes for genetic improvement of preweaning growth traits in Frisian calves in Egypt. Pakistan J. Biol. Sci., 9 (4):723.

Oudah, E.Z.M. and A.F.A. Mehrez, 2000. Genetic and some non-genetic factors affecting preweaning body weight and growth rate of Friesian calves in Egypt. Proc. of the $3^{\text {rd }}$ All Africa Conf. on Animal
Agric. and $11^{\text {th }}$ Conf. Egyptian Soc. for Anim. Prod., Alex., Egypt, 6-9 Nov., pp: 689.

Sahin A., Z. Ulutas, A. Yilmaz Adkinson and R.W. Adkinson, 2012. Estimates of phenotypic and genetic parameters for birth weight of Brown Swiss calves in Turkey using an animal model. Trop Anim Health Prod . 44:1027.

Segura-Correa, J.C., R.C. Chin-Colli; J.G. Magaña-Monforte and R. NúñezDomínguez, 2012. Genetic parameters for birth weight, weaning weight and age at first calving in Brown Swiss cattle in Mexico. Trop. Anim. Health Prod. 44:337.

Shahzad F., M. Yaqoob, M. Younas, U. Farooq, F. Sher, M. Asim, S. Qamar, M. Akbar and I. Irshad, 2010. Factors affecting the birth weight of Cholistani cattle calves. Pak Vet J, 30(4): 247.

Sharma, A., 1982. Breeding and selection methods for maximizing profit function in buffaloes. Ph.D. Thesis, Kurukshetra Univ., India, p.114.

Sharma, A. and S.B. Basu, 1986. incorporation of profit variables for the maximization of genetic gain. Indian J. Dairy Sci., 39:35.

Shemeis, A.R., M.H. Sadek and N.A. Shalaby, 2006. Selection indexes for improving growth rate in Friesian heifers with minimum concomitant increase in birth weight. Egyptian J. Anim. Prod., 43(2):83.

Swali, A., and D.C, Wathes, 2006. Influence of dam and sire on size at birth and subsequent growth, milk production and fertility in dairy heifers. Theriogenology, 66, 1173.

Vandepitte, W.M., and L.N. Hazel, 1977. The effect of errors in the economic weights on the accuracy of selection indexes. Annuals Genet. Sel. Anim. 9:87.

Van der Werf, J. and M. Goddard, 2003. Models and Methods for Genetic Analysis. Armidale Animal Breeding, Summer course, New England Univ.

Wagenaar, D., J. Arendonk, M. van, Kramer, 1995. Selection Index Program (SIP), User manual. Animal Breeding Department, Wageningen Agric. Univ., NL. 
Table 1. Mean, standard deviation (SD), and coefficient of variability (CV) for pre-weaning body weights in Friesian heifers

\begin{tabular}{lcccc}
\hline Body weight at: & № of records & Mean, $\mathbf{k g}$ & SD, $\mathbf{k g}$ & CV, \% \\
\hline Birth (W0) & 1748 & 32.74 & 3.79 & 11.58 \\
30 day (W30) & 1309 & 40.71 & 4.32 & 10.61 \\
60 day (W60) & 1309 & 49.08 & 4.61 & 9.39 \\
90 day $(W W)$ & 1748 & 82.47 & 5.07 & 6.15 \\
\hline
\end{tabular}

Table 2. Different estimates of relative economic values for pre-weaning body weights and its rank correlations in Friesian heifers

\begin{tabular}{|c|c|c|c|c|c|c|c|c|}
\hline \multirow[b]{2}{*}{ Body weight at: } & \multicolumn{8}{|c|}{$\begin{array}{l}\text { Relative Economic Values } \\
\end{array}$} \\
\hline & $\begin{array}{c}\text { V1 } \\
\text { Reg } \\
\text { (Beta) }\end{array}$ & $\begin{array}{c}\text { V2 } \\
\text { Reg } \\
\text { (b) }\end{array}$ & $\begin{array}{c}\text { V3 } \\
\text { Lamont }\end{array}$ & $\begin{array}{c}\text { V4 } \\
\text { Sharma }\end{array}$ & $\begin{array}{c}\text { V5 } \\
\text { profit } \\
\mathbf{2 0 0 4}\end{array}$ & $\begin{array}{c}\text { V6 } \\
\text { profit } \\
2012 \\
\end{array}$ & $\begin{array}{c}\text { V7 } \\
\text { FAO } \\
2011\end{array}$ & $\begin{array}{c}\text { V8 } \\
\text { Unity } \\
\text { Case }\end{array}$ \\
\hline Birth (W0) & 0.581 & 0.677 & 0.913 & 1.338 & 0.806 & 1.091 & 1.208 & 1 \\
\hline 30 day (W30) & 0.403 & 0.328 & 0.700 & 1.174 & 0.452 & 0.333 & 0.371 & 1 \\
\hline 60 day (W60) & 0.539 & 0.214 & 0.750 & 1.100 & 0.545 & 0.667 & 0.360 & 1 \\
\hline 90 day (WW) & 1 & 1 & 1 & 1 & 1 & 1 & 1 & 1 \\
\hline Rank Correlation & V1 & $\mathbf{V 2}$ & V3 & V4 & V5 & V6 & V7 & V8 \\
\hline $\operatorname{Reg}($ Beta $)$ & 1 & .800 & $.999(* *)$ & -.400 & $.999(* *)$ & .700 & .600 & - \\
\hline $\operatorname{Reg}(b)$ & & 1 & .800 & -.200 & .800 & .600 & .700 & - \\
\hline Lamont & & & 1 & -.400 & $.999(* *)$ & .700 & .600 & - \\
\hline Sharma & & & & 1 & -.400 & .200 & .400 & - \\
\hline Profit-2004 & & & & & 1 & .700 & .600 & - \\
\hline Profit-2012 & & & & & & 1 & .700 & - \\
\hline
\end{tabular}
** Significant at 0.01

Table 3. Standard deviation ${ }_{(\sigma p)}$, heritability ${ }_{( \pm \mathrm{SE})}$ estimates $_{(\text {diagonal) }}$, genetic ${ }_{(b e l o w)}$ and phenotypic (above) correlations among studied body weights in Friesian heifers

\begin{tabular}{llccccc}
\hline Body weight at: & $\sigma_{\mathrm{p}}, \boldsymbol{k g}$ & W0 & W30 & W60 & WW \\
\hline Birth & (W0) & 3.79 & $0.23 \pm 0.19$ & 0.647 & 0.519 & 0.626 \\
30 day & (W30) & 4.32 & 0.629 & $0.30 \pm 0.13$ & 0.723 & 0.539 \\
60 day & (W60) & 4.61 & 0.495 & 0.616 & $0.28 \pm 0.21$ & 0.654 \\
90 day & (WW) & 5.07 & 0.753 & 0.625 & 0.519 & $0.21 \pm 0.27$ \\
\hline
\end{tabular}


Table 4. Weighing factors (b-values), standard deviation of the index ( $\sigma \mathrm{i})$, efficiencies of selection in absolutes $\left(\mathbf{R}_{\mathrm{Ih}}\right)$, and Expected genetic gains per generation at $(i=1)$ for selection indices used to improve pre-weaning body weights in Friesian heifers

\begin{tabular}{|c|c|c|c|c|c|c|c|c|c|c|c|c|c|c|}
\hline \multirow[t]{2}{*}{$\begin{array}{l}\text { General } \\
\text { Selection } \\
\text { indices }\end{array}$} & \multicolumn{4}{|c|}{ b-values } & \multirow[t]{2}{*}{$\sigma \mathbf{i}$} & \multirow[t]{2}{*}{$\mathbf{R}_{\mathrm{Ih}}$} & \multicolumn{4}{|c|}{$\begin{array}{c}\text { Expected genetic gain } \\
(\Delta G \text { per kg }) \\
(i=1)\end{array}$} & \multicolumn{4}{|c|}{$\begin{array}{c}\text { Difference of } \Delta G \text { for } \\
\left(V_{1-7}-\text { Unity case }\right) \\
\text { as a percentage } \\
\end{array}$} \\
\hline & W0 & W30 & W60 & WW & & & W0 & W30 & W60 & WW & W0 & W30 & W60 & WW \\
\hline I 1- Reg(Beta) & 0.0424 & 0.3310 & 0.0638 & 0.1745 & 2.404 & 0.5051 & 0.678 & 1.184 & 1.009 & 0.989 & $0.3 \%$ & $-3.3 \%$ & $-8.3 \%$ & $9.9 \%$ \\
\hline I2- $\operatorname{Reg}(b)$ & 0.0707 & 0.2917 & -0.0381 & 0.2024 & 2.077 & 0.4998 & 0.706 & 1.133 & 0.863 & 1.043 & $4.4 \%$ & $-7.4 \%$ & $-21.5 \%$ & $15.9 \%$ \\
\hline I3- Lamont & 0.0955 & 0.4493 & 0.1306 & 0.1531 & 3.206 & 0.5117 & 0.691 & 1.207 & 1.057 & 0.937 & $2.2 \%$ & $-1.4 \%$ & $-3.9 \%$ & $4.1 \%$ \\
\hline I4- Sharma & 0.1569 & 0.6359 & 0.2410 & 0.1194 & 4.454 & 0.5180 & 0.691 & 1.222 & 1.099 & 0.886 & $2.2 \%$ & $-0.2 \%$ & $-0.1 \%$ & $-1.5 \%$ \\
\hline I5- Profit-2004 & 0.0899 & 0.3539 & 0.0660 & 0.1708 & 2.625 & 0.5047 & 0.702 & 1.180 & 1.002 & 0.978 & $3.8 \%$ & $-3.6 \%$ & $-8.9 \%$ & $8.7 \%$ \\
\hline I6- Profit-2012 & 0.1594 & 0.3294 & 0.1045 & 0.1532 & 2.811 & 0.5002 & 0.728 & 1.158 & 1.015 & 0.954 & $7.6 \%$ & $-5.4 \%$ & $-7.7 \%$ & $6.0 \%$ \\
\hline I7- FAO-2011 & 0.1849 & 0.3287 & 0.00833 & 0.1806 & 2.644 & 0.4979 & 0.752 & 1.133 & 0.9134 & 0.987 & $11.2 \%$ & $-7.4 \%$ & $-17.0 \%$ & $9.7 \%$ \\
\hline I8- Unity & 0.09379 & 0.5637 & 0.2092 & 0.1321 & 3.9 & 0.5179 & 0.6763 & 1.224 & 1.1 & 0.8998 & - & - & - & - \\
\hline
\end{tabular}

$i=$ selection intensity; $\Delta \mathbf{G}=$ Expected genetic gain per generation.

Table 5. The Spearman rank correlation among general indices for different economic values

\begin{tabular}{|c|c|c|c|c|c|c|c|}
\hline $\begin{array}{c}\text { Methods of Economic } \\
\text { Values } \\
\end{array}$ & $\begin{array}{c}\text { V2 } \\
\operatorname{Reg}(b)\end{array}$ & $\begin{array}{c}\mathrm{V3} \\
\text { Lamont }\end{array}$ & $\begin{array}{c}\text { V4 } \\
\text { Sharma }\end{array}$ & $\begin{array}{c}\text { V5 } \\
\text { Profit-2004 } \\
\end{array}$ & $\begin{array}{c}\text { V6 } \\
\text { Profit-2012 } \\
\end{array}$ & $\begin{array}{c}\text { V7 } \\
\text { FAO-2011 } \\
\end{array}$ & $\begin{array}{c}\mathrm{V8} \\
\text { Unity Case } \\
\end{array}$ \\
\hline V1- Reg(Beta) & $.839(* *)$ & $.994(* *)$ & $.783(*)$ & $.999(* *)$ & $.897(* *)$ & $.908(* *)$ & $.854(* *)$ \\
\hline V2- $\operatorname{Reg}(b)$ & & $.804(* *)$ & $.870(* *)$ & $.946(* *)$ & $.834(* *)$ & $.726(* *)$ & $.906(* *)$ \\
\hline V3- Lamont & & & $.997(* *)$ & $.993(* *)$ & $.795(*)$ & $.940(* *)$ & $.806(* *)$ \\
\hline V4- Sharma & & & & $.981(* *)$ & $.786(*)$ & $.959(* *)$ & $.767(* *)$ \\
\hline V5- Profit-2004 & & & & & $.899(* *)$ & $.899(* *)$ & $.850(* *)$ \\
\hline V6- Profit-2012 & & & & & & $.910(* *)$ & $.835(* *)$ \\
\hline V7- FAO-2011 & & & & & & & $.678(* *)$ \\
\hline
\end{tabular}

* Siginificant at $0.05, * *$ Siginificant at $0.01, \mathrm{Reg}=$ regression. 


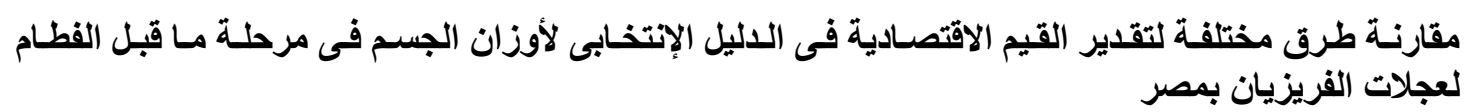

إسلام فيض الله عباس، الهام محمد غنيم

قسم الإنتاج الحيوانس، كلية الزراعة، جامعة المنوفية، مصر

أجريت هذه الدراسة للمقارنة بين طرق مختلفة لتقدير القيم الاقتصادية بواسطة ما يلى: طريقة الانحدار (بيتا-معامل الانحدار

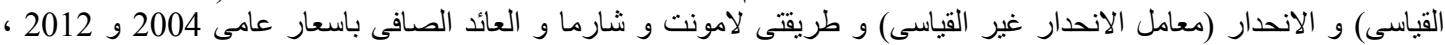

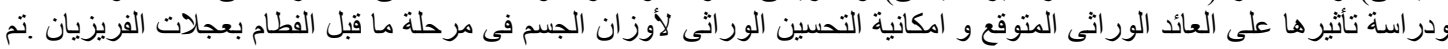

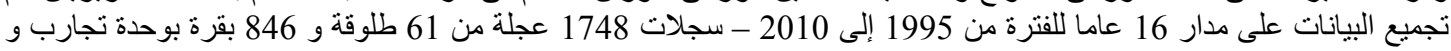

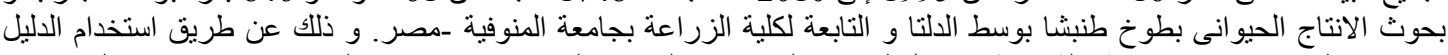

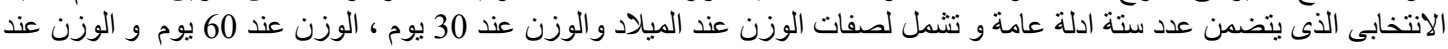

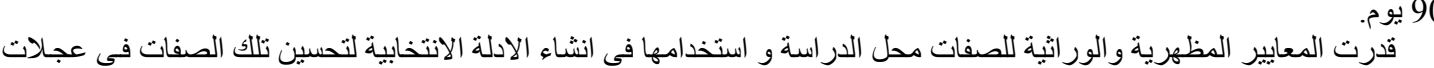

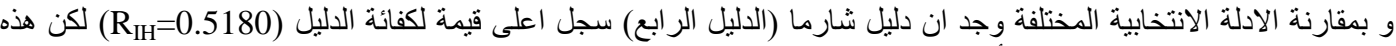
الفريزيان.

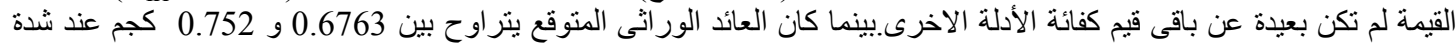

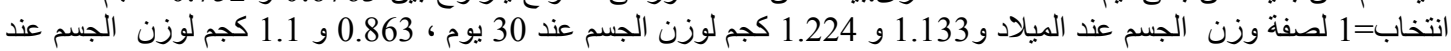
60 يوم و0.886 و 1.043 لوزن الوزن الجسم عند 90 يوم على التوالى.

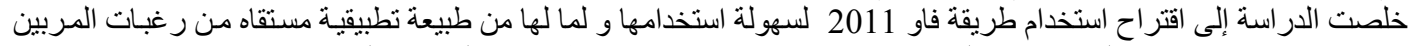

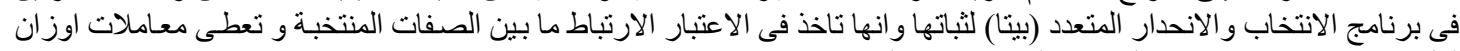
لكل صفة منتخبة باتجاه اكثر الصفات المستهدفة في البرنامج الانتخابى. 